\title{
Role of vitamin D receptor (VDR) genetic polymorphism in onset of type 2 diabetes mellitus: A Review
}

\author{
Naila Abdul Sattar ${ }^{1 *}$, Fatma Hussain ${ }^{2}$, Kathleen Gillespie ${ }^{4}$, Siraj Udin Sajid ${ }^{5}$, Sumera \\ Shaheen ${ }^{1}$, Nusrat Shafiq ${ }^{3}$, Sobia Aleem ${ }^{1}$ and Sadia Aslam ${ }^{1}$ \\ ${ }^{1}$ Department of Bio-Chemistry, Government College Women University, Faisalabad-38000. \\ ${ }^{2}$ Department of Bio-Chemistry, University of Agriculture, Faisalabad-38000. \\ ${ }^{3}$ Department of Bio-Chemistry, Government College Women University, Faisalabad-38000. \\ ${ }^{4}$ Diabetes and Metabolism, School of Clinical Sciences Faculty of Health Sciences, Level 2, Learning and Research, \\ Southmead Hospital, University of Bristol, Bristol BS10 5NB. \\ 5Department of Pathology, Rai Medical College, Sargodha 40100. \\ *Corresponding author. Email: uaf_naila_sattar@yahoo.com,dr.naila.sattar@gcwuf.edu.pk. Tel: +92 3360073152.
}

Copyright @ 2019 Sattar et al. This article remains permanently open access under the terms of the Creative Commons Attribution License 4.0, which permits unrestricted use, distribution, and reproduction in any medium, provided the original work is properly cited.

Received 2nd August, 2018; Accepted 11th September, 2018

\begin{abstract}
Numerous studies disclosed the independent role of VDR genetic polymorphisms involved in pathogenesies of various metabolic disorders like type 2 diabetes mellitus in different populations, however no any conclusive or even key study conducted on South Asian population especially Pakistani population except on Indian population. Worldwidle, vitamin D defeciency and type 2 diabetes mellitus (T2DM) are two interlated and most common health problems. Such interlationship is involved complex inheritance pattern. The polymorphisms of various genes including vitamin $D$ receptor (VDR) might affect genetic susceptibility of T2DM by developing malfunctioning of beta pancreatic cells or insulin resistance. Genetic architecture of T2DM is different among various ethnic populations. The present review will focus on concept that polymorphism of VDR gene may has role in susceptibilty of onset of T2DM and its pathogenesises.
\end{abstract}

Keywords: Pathogenesis, T2DM, VDR polmorphism.

\section{INTRODUCTION}

Diabetes mellitus is endocrinological health issue which is reaching epidemic extents globally. Such increase in T2DM prevalence is endorsed by various environmental and genetic factors. Financial impact of T2DM is incalculably arduous as approximate anticipated cost of Pakistan's health centers will be up to $\$ 490$ billion in coming ten years (Hussain et al., 2014). Common pathophysiological complications of T2DM are micro- and macro-vascular diseases, nephropathy and neuropathy. Such complications may develop due to sustained hyperglycemia, insulin resistance and dysfunction of beta cells (Ishaq et al., 2013; Sohial, 2014; Orozco et al., 2008). Insulin resistance established in early development lead to type 2 diabetes mellitus. With passage of time the compensatory reaction of pancreatic beta cells becomes weakened and leads to sustained hyperglycemia (van de
Bunt et al., 2014; Maedler, 2008; Zanuso et al., 2010).

T2DM patients have significantly higher risk for a variety of vascular complications; retinopathy, neuropathy, atherosclerosis, cardiovascular diseases, hypertension leading to infections (Sreelatha et al., 2015). Perhaps there are a number of different causes of T2DM, though exact etiologies are still not known. Combination of genetic and environmental factors that contribute to T2DM onset are life style, dietary habit, BMI, hypovitaminosis $D$ and family history (Sreelatha et al., 2015; Konstantinos et al., 2017; Zheng et al., 2018).

Physical inactivity and obesity are consequences of overweight which contribute to prone T2DM through insulin resistance. Obesity is prevalent in developed and developing countries even in urban part of the world. Predominant distribution of fat in non-obese people is 
accountable of T2DM. Although a few etiological hazards for the development of insulin resistance and dysfunction of beta cell have been recognized, gaps remain in understanding etiology of such disorders. In addition, factors associated with the longitudinal evolution of these diseases have received very limited studies (American Diabetes Association, 2015).

Both acquired and genetic factors are measured to have imperative roles in onset T2DM. First degree relatives and monozygotic twins affected $50 \%$ to T2DM due to heritability (Pierce et al., 1995; Herder and Roden, 2011). More than 50 various genes are related to T2DM (Imamura and Maeda, 2011; Wheeler and Barroso, 2011). Obesity and low socioeconomic are considered major risk factor for T2DM after genetic menaces (Fagard and PNilsson, 2009; Meigs, 2010).

\section{BETA CELL DYSFUNCTION AND INSULIN SENSITIVITY}

In normal physiological reaction to increased level of glucose in blood, insulin synthesized from beta cells binds to the insulin receptors present on plasma membrane of insulin target tissues, which consequently persuades a cascade of signaling transduction to permit for the transportation of glucose in the cell for glucose consumption. Although, in reduced insulin sensitivity state, there can be defects at insulin receptor location or in signaling the pathway, which results in diminished insulin action and thus lower amounts of glucose being transported into the cell (Bloomgarden, 1998; Kadowaki et al., 2007; Shoelson and Donath, 2011) and typical lifestyle features; stress, smoking, less use of dietary fibers and magnesium (Reaven and Tsao, 2003). Lack of insulin sensitivity is also causing polycystic ovary syndrome and fatty liver (Lima et al., 2009; Bethea and Nestler, 2008).

In case of dysfunction of beta cells, the concentration of insulin synthesized cannot overwhelm the lack of insulin sensitivity in multiple organs, subsequently resulting in hyperglycemia (Maedler, 2008). Therefore, though both dysfunction of pancreatic beta cells and lack of insulin sensitivity take part in the development of T2DM, it is certainly dysfunction of beta cells that is serious to the progression of the diseases diabetes mellitus cannot arise deprived of impairment of the insulin production (Maedler, 2008; Gastaldelli, 2011). Limited knowledge exists about the etiology of dysfunction of pancreatic beta cells, however; both environmental and genetic factors are considered to play a role. Few plausible menaces which have currently been recognized involve glucotoxicity to the beta cell which would be the outcome of prolonged enduring hyperglycemia, lipotoxicity caused by elevated levels of free fatty acid that often coexist in people with higher adiposity and lack of insulin (Bonora, 2008), oxidative stress and long-lasting subclinical inflammation (Greenberg and McDaniel, 2002), additional visceral adipose tissue (Hanley et al., 2003; Utzschneider et al., 2004), lack of insulin sensitivity of pancreatic beta cells (Bonora, 2008) and low adiponectin (Kharroubi et al., 2003; Bacha et al., 2004). Family histories as well as genetics are also considered to take part in defining risk of dysfunction of pancreatic beta cells (Marchetti et al., 2002; Marchetti et al., 2006).

\section{VITAMIN D}

Vitamin D (Figure 1) is necessary for the homeostasis of calcium to prevent rickets and osteomalacia (Norman, 1998). In teenagers, hypovitaminosis $D$ predisposes to rickets, a disorder of bones characterized by poor mineralization of skeletal tissues causing retardation of growth and deformities of skeletal comprising bony projections with rib cage and deformed legs or collided knees. In old age people, hypovitaminosis $D$ develops osteomalacia, a defect in mineralization producing tender bone pain and weakness of muscles (Holick, 2003; Holick, 2011).

\section{Sources of Vitamin D}

Mostly the cutaneous production of vitamin D after the exposure to sunlight is considered to be main source in which mainly ultraviolet $B$ (UVB) radiation of sunlight (290 to $315 \mathrm{~nm}$ ) commence the photochemical reaction (Holick et al., 2007). Furthermore, other than this endogenous synthesis, humans can also get vitamin $D$ through food supply. Almost all food sources are initiated from ultra violet radiation of plant ergosterol and sterol, present in plasma membranes of both fungus and yeast and synthesizing vitamin $D_{2}$ or ergocalciferol and vitamin $D_{3}$ or cholecalciferol by animal sources (Calvo et al., 2004; Calvo et al., 2005).

However, vitamin $D_{2}$ is less effective as compared to vitamin $D_{3}$ in raising serum concentrations of vitamin $D$ (Tripkovic et al., 2012) and suggested that vitamin $\mathrm{D}_{3}$ can be employed for clinical as well as nutritional demands (Vieth, 2009).

\section{Metabolism of Vitamin D}

Cholcalciferol enters blood stream through binding to protein known as vitamin $\mathrm{D}$ binding protein (DBP) and undergoes hydroxylation through cytochrome P450 enzyme hydroxylase (CYP2R1) to 25-hydroxyvitamin D also known as calcidiol in liver. Calicidiol is the chief circulating type of this vitamin in body (DeLuca, 2004; Strushkevich et al., 2008). Subsequently, 25hydroxyvitamin $D$ is then transported to kidneys where 1alpha-hydroxylase converts 25-hydroxyvitamin $D$ into active metabolite of vitamin $D$ that is 1,25 -dihydroxyvitamin 
D or calcitriol (Sakaki et al., 2005).

Circulating 25-hydroxyvitamin D may be transported to tissues by two different processes; it may move directly across the cell membrane or bound to binding protein in the circulation to reach target tissues, predominantly to kidneys through megalin of the endocytic receptor (Nykjaer et al., 1999). The process of hydroxylation of the vitamin $D$ in liver is not firmly regulated, while renal production of 1,25 -hydroxyvitamin $D$ is strongly regulated through calcium, phosphorous, parathyroid hormone and 1, 25-hydroxyvitamin D itself (Breslau, 2008). When levels of calcium in blood are not sufficient, parathyroid hormone levels are elevated which stimulate calcitriol production consequently enhancing the absorption of calcium in the intestine (Segersten et al., 2002). Maintenance of nonrenal dihydroxyvitamin $\mathrm{D}$ production is mostly unknown, however, alpha hydroxylase mRNA is maximum in renal tissues (Omdahl et al., 2002).

About 2 to $3 \%$ of the human genome is indirectly or directly regulated through vitamin $\mathrm{D}$ coordination (Bouillon et al., 2008). Furthermore, it has been established that locally produced dihydroxyvitamin $\mathrm{D}$ may control more than 2000 genes which take part in various processes comprising immunity, cell growth, inflammation and cell proliferation (Nagpal et al., 2005; Norman, 2006). The genomic function of vitamin $D$ requires the joining of calcitriol to strong affinity receptor, vitamin $\mathrm{D}$ receptor (VDR). It is a member of superfamily of the nuclear hormone receptors which acts as a ligand activated transcription factor (Ogunkolade et al., 2002). However, the VDR can be present in organs involve in metabolism of calcium and homeostasis constituting the bone, intestine, parathyroid glands and kidney. VDRs have also been recognized in many other tissues: breast, heart, colon, pancreas and prostate (Anderson et al., 2003; Clemens et al., 2009).

Moreover, besides genomic function, vitamin D also facilitates a rapid non-genomic function that is found through the attachment of vitamin $D$ to a cell membrane VDR. Such non-genomic functions of vitamin D are vital in nuclear transcription activity, and the membrane associated actions, such as elevating calcium uptake, secretion of calcium from its intracellular stores and excitement of protein kinase C action (Norman, 2006; Fleet, 2004).

\section{Factors affecting vitamin $D$ levels}

A number of factors may affect the production of vitamin $D$ in vivo. Solar zenith angle (SZA), that is the role of time of day, latitude and time of year significantly affects the relationship of vitamin D synthesis and sunlight exposure (Kimlin, 2008).

Dark skin coloration is also important influential factor for dermal vitamin $\mathrm{D}$ production, due to less absorption of ultraviolet radiations with higher melanin component.
People with intensive skin pigmentation contain high melanin component that absorbs ultraviolet photons and therefore contends along 7-dehydrocholesterol (Clemens et al., 2009). Prevention of sunlight exposure, wrapping of body by clothing as well as sunscreen routine also decreases dermal synthesis of vitamin $D$ (Holick et al., 2007; Fleet, 2004).

The composition of body is another significant indicative factor for vitamin D level, as different studies have constantly revealed that people with higher adiposity have poor levels of vitamin D (Liel et al., 1999; Arunabh et al., 2003) due to repossession of fat soluble vitamins in adipocytes (Wortsman et al., 2003; Blum et al., 2008). Furthermore, people with disorders of malabsorption; fibrosis, cystic, celiac and Chron's diseases have reduced bioavailability of vitamin $D$ because of a diminished capability to absorb this vitamin (Lo et al., 2005). People with kidney and liver disorders also suffer from deficiency of vitamin $D$ because of impairments in metabolism of vitamin D (Masuda et al., 1999; Ishimura et al., 2000).

Genetic influences are another important determinant of levels of vitamin $\mathrm{D}$ and take part in inter-individual deviation in vitamin $D$ considerably influencing both quantities and variation in synthesis (Arguelles et al., 2009; Karohl et al., 2010). The VDR gene and other genes polymorphisms, as all genes exhibit inclusively variable contributions in production, function and metabolism of vitamin D.

\section{Vitamin D and type 2 diabetes mellitus}

The actions of vitamin $\mathrm{D}$ upon skeletal health are indicating its significant action in many other disorders and health conditions including; cardiovascular diseases, cancer, autoimmune disorders, and T2DM (Holick, 2011; Boyd et al., 1986). Deficiency of vitamin D is related with reduced insulin secretion, and supplementation of vitamin D reestablished normal insulin secretion (Norman et al., 2004; Clark et al., 2010). Moreover, seasonal changes in insulin and glucose concentrations (Behall et al., 2004; de Souza and Meier, 2007), as well as seasonal changes in diagnosis and management of T2DM have been noted. There are more diagnosis and lesser glycemic control during winter as compared to summer (Doro et al., 2006). Furthermore, most case control research outcomes have also documented that T2DM patients or those with impaired tolerance of glucose are expected to have a poor concentration of vitamin D than to those without T2DM (Pittas et al., 2006; Scragg et al., 2004).

Only two randomized control trials suggesting the effects of this vitamin supplementation on incidence of T2DM are available in literature (de Boer et al., 2008; Avenell et al., 2009), as most of these trials stated the effects of vitamin D on insulin resistance, glycemic control and insulin secretion in preliminary inferences and determined no statistically significant action of vitamin $D$ supplementation 
[400 IU/day] (de Boer et al., 2008); $800 \mathrm{IU} /$ day (Avenell et al., 2009) on occurrence of diabetes mellitus after three to seven years of follow-up.

\section{Association of vitamin D and insulin resistance}

A number of researches have examined the function of vitamin $D$ in initial pathophysiological conditions underlying T2DM, especially lack of insulin sensitivity and pancreatic beta cell dysfunction. A significant role of this vitamin with lack of insulin and pancreatic beta cell function has been derived. Uneven outcomes have also been stated in cross sectional analyses considering the relationship of vitamin $D$ with function of the beta cell, indicating a positive association (Boucher et al., 1995; Baynes et al., 1997; Wu et al., 2009) or no significant relationship (Orwoll et al., 1994; Chiu et al., 2004; Scragg et al., 2004; Gulseth et al., 2010; Del Gobbo et al., 2011; Rhee et al., 2012).

\section{Mechanism}

Numerous prospective processes have been recommended to describe the relationship of vitamin $D$ to T2DM and its associated manifestations. Vitamin D can directly increase action of insulin for the transportation of glucose via exciting the expression of insulin receptors (Maestro et al., 2000), as (vitamin D response element) VDRE is located in promoter region of insulin receptor gene (Maestro et al., 2003). Vitamin D cannot directly affect lack of insulin sensitivity by maintaining intracellular processing of insulin mediated by the regulation of calcium pool (Draznin et al., 1987; Draznin, 1988). Elevated intracellular calcium may stop insulin target cells to sense sharp intracellular fluctuations in calcium which is necessary for insulin action involving glucose transport (Norman et al., 2004; Worrall and Olefsky, 2002). This is also significant to note that initial determinants of peripheral sensitivity of insulin, skeletal muscle and adipocytes, express the VDR (Norman, 2006; Bischoff et al., 2001) and like sensitivity of insulin, the expression of VDR decline in skeletal muscle with age (Bischoff-Ferrari et al., 2004). In addition, the expression of vitamin D ahydroxylase observed in various tissues of wistar rats ( $\mathrm{Li}$ et al., 2008), initiating the local synthesis of vitamin D. With respect to pancreatic beta cell function, calcitriol can apply direct effects by binding of its active form in circulation to the beta cell VDR (Johnson et al., 1994; Zeitz et al., 2003). Instead, activation of this vitamin could happen within the pancreatic beta cell by vitamin D 1- $\alpha$-hydroxylase that has been designated to express in pancreatic beta cells (Bland et al., 2006). Furthermore, assuming the occurrence of VDRE in insulin gene promoter region, this may interpret the transcriptional activation of insulin gene through vitamin D (Maestro et al., 2003). Vitamin D can also employ indirect effect on beta cell function by maintaining extracellular calcium and its flux through the beta cell (Sergeev and Rhoten, 1995) as secretion of insulin is a calcium dependent phenomenon (Holick, 2011). Based on the relationship between T2DM and systemic inflammation (Donath and Shoelson, 2011) vitamin D may also improve the sensitivity of insulin and promote the function of the beta cell by regulating the generation and actions of cytokines (Pittas et al., 2007). However, limited data have described the association between vitamin D and T2DM (Pittas et al., 2007; Cigolini et al., 2006).

\section{Role of genetics}

Genetic variations can explain discrepancies in the literature with respect to the relationship of vitamin $D$ to T2DM. Much research has been focused on various genotypes associated to the VDR, vitamin D binding protein (DBP) and vitamin D-1-a-hydroxylase. Polymorphisms that have been recognized in VDR gene, specifically Apal, Taql, Fokl and Bsml may be related with T2DM, lack of insulin sensitivity and dysfunction of the pancreatic beta cell. However, recent evidences are limited and their outcomes have been inconsistent. Studies have found imperative relationships of specific VDR polymorphisms with higher lack of insulin sensitivity (Chiu et al., 2001; Oh et al., 2002; Ortlepp et al., 2002; Filus et al., 2003; Tworowska-Bardzinska et al., 2008) and insulin secretion (Hitman et al., 1998; Speer et al., 2001; Ogunkolade et al., 2002). Though, most of these researches have focused on Caucasian populations and have employed surrogate measures of beta cells functions and lack of insulin based during fasting. With regard to T2DM specifically, Ortlepp et al. (2001) observed a greater prevalence of T2DM among those with a certain Bsml genotype for VDR gene as compared to those deprived of this genotype. Some case-control studies described no significant variations in frequencies of the genotype for different VDR genes in T2DM versus controls (Ortlepp et al., 2001; Boullu-Sanchis et al., 1999; Ye et al., 2001; Malecki et al., 2003; Bid et al., 2009; Dilmec et al., 2010; Vural et al., 2012). Therefore, further investigation into association between VDR polymorphisms and risk of T2DM is warranted predominantly in various ethnic populations. Genetic polymorphisms of the vitamin binding protein have been recognized suggesting an association of these polymorphisms and enhanced risk of T2DM (Hirai et al., 1998) and lack of insulin sensitivity as calculated through fasting glucose or levels of insulin (Baier, 1996; Szathmary 2007). However, another gene related to vitamin $D$ studied for a possible association with T2DM is vitamin D-1-a-hydroxylase (CYP1alpha), it is accountable for the change of hydroxyvitamin $D$ to dihydroxyvitamin $D$ (calcitriol). So far, single study has been done to date (Malecki et al., 2003), which suggested no significant polymorphism in CYP1alpha gene in T2DM patients versus controls in the Polish population. Hence, significant 
association of specific genotype of CYP1alpha gene with T2DM was observed in obese subgroup. However, precise mechanism of this finding was not clear. Earlier, Jorde et al. (2012) suggested that no significant relationship of T2DM exist with many single nucleotide polymorphisms (SNP) linked with serum vitamin D level.

\section{Vitamin D receptor polymorphisms}

Four allelic variants of vitamin $D$ receptor gene have been recognized: Apal, Fokl, Bsml and Taql (Pittas et al., 2006). The functions of these vitamin $D$ receptor polymorphisms have been comprehensively studied in T2DM patients (Ogunkolade et al., 2002). Polymorphism genotype Apal of VDR gene showed relationship to the insulin secretion in Bangladeshi population, which are at high risk of T2DM with higher prevalence of hypovitaminosis $\mathrm{D}$. A correlation of Apal polymorphism with fasting blood glucose level and intolerance of glucose was evident among those people who had diabetes symptoms at pre-diagnosis stage. Ogunkolade et al. (2002) illustrated a positive relationship between the Bsml (genotype bb) and Taql (genotype TT) polymorphisms with decreased insulin secretory potential. Speer et al. (2001) proposed that obese T2DM patients have greater levels of $\mathrm{C}$ - peptide and VDR polymorphism of Bsml allele (BB-genotype) indicative of their probable role in pathogenesis of T2DM. Insufficiency of vitamin D was measured in these subjects and polymorphism of Taql was an element related to insulin secretion. Though, there is strong evidence of link between T2DM and VDR polymorphism; conflicting results among different populations are reported (Malecki et al., 2003).

In T2DM, the vitamin D receptor gene polymorphism of allele Apal (aa genotype) was related with impaired secretion of insulin in Caucasian population, thus this population had a higher risk of developing T2DM (Oh et al., 2002). Contrary to that, VDR gene polymorphisms of alleles Fokl, Taql, Apal and Bsml had no noteworthy association with T2DM in a case control research within Bangladeshi population by Islam et al. (2014). Insulin sensitivity was significantly decreased in T2DM cases of Bangladeshi origin.

It was concluded by Sung et al. (2012) that distributions of VDR gene alleles of the four SNPs (Bsml, Taql, Tru9l and Apal) were same in T2DM patients and controls. These evidences supporting or opposing a relationship of vitamin $\mathrm{D}$ receptor genotypes with menace of T2DM are conflicting.

Polymorphisms present in intron 8 (Bsml) and exon 9 (Taql) of vitamin D receptor gene had substantial linkage with type 2 diabetes mellitus, while distribution as well as frequency of genotype Fokl (exon 2) and Apal (exon 8) of the VDR were significantly similar in T2DM patients and healthy people. These results confirmed the previous inferences that VDR gene genotypes Bsml as well as Taql polymorphisms are related with onset of type 2 diabetes mellitus (Speer et al., 2001; Nosratabadi et al., 2010).
Furthermore, Al-Daghri et al. (2012) explained that Bsml and Taql single nucleotide polymorphisms that are significantly more common in T2DM patients were allied with elevated levels of cholesterol and lower levels of high density lipoprotein (HDL) cholesterol. However, such results are yet not unambiguous as other researchers failed to demonstrate the analogous relationship between Fokl, Apal, Bsml and Taql polymorphisms and onset of type 2 diabetes mellitus in Indians (Ortlepp et al., 2002), Turkish (Dilmec et al., 2010), Polish (Malecki et al., 2003) and American populations (Oh et al., 2002). The reasons of these discrepancies might be elucidated by the differences in the genetic background among ethnic groups. An overview of VDR gene of the significant allelic variations associated to T2DM.

Although the summary depicted below is scarce and not compatible, nonetheless it portrays a possible association between VDR gene, metabolism of vitamin D and T2DM etiology/traits.

\section{CONCLUSION}

The prevalence of T2DM is intensely increasing, both in Pakistan and worldwide. Furthermore, assuming the lack of correct diagnosis of vitamin D deficiency and multisystem implications in most populations are at greater risk of having inadequate levels of serum vitamin $D$, with over $75 \%$ people having vitamin D deficiency while $18 \%$ reported insufficient vitamin D levels (Masood et al., 2010). Evolving evidence proposes a prospective role for this vitamin in risk of T2DM as well as its underlying pathophysiological complications, specifically lack of insulin sensitivity and dysfunction of beta cell. However, many epidemiological, interventional and biological researches have suggested a probable relationship of vitamin $\mathrm{D}$ to lack of insulin sensitivity and function of beta cell, although these evidences have been inconsistent. In recent years, a number of polymorphisms, such as Bsml and Fokl have been observed in the vitamin $D$ receptor genes which are able to change the function of the VDR protein, while other polymorphisms in VDR gene found through variation of alleles in sites of restriction enzyme are Taql and Apal. The genetic background of T2DM remains unclear. However, it is suggested that the vitamin $D$ receptor gene is an innovative candidate gene responsible to the susceptibility to T2DM.

\section{CONFLICT OF INTEREST}

The authors declare that they have no conflict of interest.

\section{REFERENCES}

Al-Daghri, N. M., Al-Attas, O., Alokail, M. S., Alkharfy, K. M., Draz, H. M., Agliardi, C., Mohammed, A. K., Guerini, F. R. \& Clerici, M. (2012). Vitamin D receptor gene polymorphisms and 
HLA DRB1* 04 cosegregation in Saudi type 2 diabetes patients. The Journal of Immunology, 188, 1325-1332.

American Diabetes Association (2015). Diabetes Care. 38(Suppl. 1), S3-S3. https://doi.org/10.2337/dc15-S002.

Anderson, P. H., May, B. K., \& Morris, H. A. (2003). Vitamin D metabolism: new concepts and clinical implications. The Clinical Biochemist Reviews, 24(1), 13-26.

Arguelles, L. M., Langman, C. B., Ariza, A. J., Ali, F. N., Dilley, K., Price, H., Liu, X., Zhang, S., Hong, X., Wang, B., \& Xing, H. (2009). Heritability and environmental factors affecting vitamin D status in rural Chinese adolescent twins. The Journal of Clinical Endocrinology and Metabolism, 94(9), 3273-3281.

Arunabh, S., Pollack, S., Yeh, J., \& Aloia, J. F. (2003). Body fat content and 25-hydroxyvitamin D levels in healthy women. The Journal of Clinical Endocrinology and Metabolism, 88(1), 157161.

Avenell, A., Cook, J. A., MacLennan, G. S., \& McPherson, G. C. RECORD Trial Group 2009 Vitamin D supplementation and type 2 diabetes: a sub study of a randomised placebocontrolled trial in older people (RECORD Trial, ISRCTN 51647438). Age Ageing, 38, 606-609.

Bacha, F., Saad, R., Gungor, N., \& Arslanian, S. A. (2004). Adiponectin in youth: relationship to visceral adiposity, insulin sensitivity, and $\beta$-cell function. Diabetes Care, 27(2), 547-552.

Baier, L. (1996). The Pima Diabetes Genes Group: suggestive linkage of genetic markers on chromosome $4 q 12$ to NIDDM and insulin action in Pima Indians: new evidence to extend associations in other populations. Diabetes, 45(Suppl 2), 30A.

Baynes, K. C. R., Boucher, B. J., Feskens, E. J. M., \& Kromhout, D. (1997). Vitamin D, glucose tolerance and insulinaemia in elderly men. Diabetologia, 40(3), 344-347.

Behall, K. M., Scholfield, D. J., Hallfrisch, J. G., Kelsay, J. L., \& Reiser, S. (1984). Seasonal variation in plasma glucose and hormone levels in adult men and women. The American Journal of Clinical nutrition, 40(6), 1352-1356.

Bethea, S. W., \& Nestler, J. E. (2008). Comorbidities in polycystic ovary syndrome: their relationship to insulin resistance. Panminerva Medica, 50(4), 295-304.

Bid, H. K., Konwar, R., Aggarwal, C. G., Gautam, S., Saxena, M., Nayak, V. L., \& Banerjee, M. (2009). Vitamin D receptor (Fokl, $\mathrm{Bsml}$ and Taql) gene polymorphisms and type 2 diabetes mellitus: a North Indian study. Indian Journal of Medical Sciences, 63(5), 187-194.

Bischoff, H. A., Borchers, M., Gudat, F., Duermueller, U., Theiler, R., Stähelin, H. B., \& Dick, W. (2001). In situ detection of 1, 25dihydroxyvitamin $\mathrm{D}$ receptor in human skeletal muscle tissue. The Histochemical Journal, 33(1), 19-24.

Bischoff-Ferrari, H. A., Borchers, M., Gudat, F., Dürmüller, U., Stähelin, H. B., \& Dick, W. (2004). Vitamin D receptor expression in human muscle tissue decreases with age. Journal of Bone and Mineral Research, 19(2), 265-269.

Bland, R., Markovic, D., Hills, C. E., Hughes, S. V., Chan, S. L., Squires, P. E., \& Hewison, M. (2004). Expression of 25hydroxyvitamin D3-1a-hydroxylase in pancreatic islets. The Journal of Steroid Biochemistry and Molecular Biology, 89, 121-125.

Bloomgarden, Z. T. (1998). Insulin resistance: current concepts. Clinical Therapeutics, 20(2), 216-231.

Blum, M., Dolnikowski, G., Seyoum, E., Harris, S. S., Booth, S. L., Peterson, J., Saltzman, E., \& Dawson-Hughes, B. (2008). Vitamin D 3 in fat tissue. Endocrine, 33(1), 90-94.

Bonora, E. (2008). Protection of pancreatic beta-cells: is it feasible? Nutrition, Metabolism and Cardiovascular Diseases, 18(1), 74-83.
Boucher, B. J., Mannan, N., Noonan, K., Hales, C. N., \& Evans, S. J. W. (1995). Glucose intolerance and impairment of insulin secretion in relation to vitamin $D$ deficiency in east London Asians. Diabetologia, 38(10), 1239-1245.

Bouillon, R., Bischoff-Ferrari, H., \& Willett, W. (2008). Vitamin D and health: perspectives from mice and man. Journal of Bone and Mineral Research, 23(7), 974-979.

Boullu-Sanchis, S., Lepretre, F., Hedelin, G., Donnet, J. P., Schaffer, P., Froguel, P., \& Pinget, M. (1999). Type 2 diabetes mellitus: association study of five candidate genes in an Indian population of Guadeloupe, genetic contribution of FABP2 polymorphism. Diabetes and Metabolism, 25(2), 150-156.

Boyd, A. E., Hill, R. S., Oberwetter, J. M., \& Berg, M. (1986). Calcium dependency and free calcium concentrations during insulin secretion in a hamster beta cell line. The Journal of Clinical Investigation, 77(3), 774-781.

Breslau, N. A. (2008). Normal and abnormal regulation of 1, 25 $(\mathrm{OH}) 2 \mathrm{D}$ synthesis. The American Journal of the Medical Sciences, 296(6), 417-425.

Calvo, M. S., Whiting, S. J., \& Barton, C. N. (2004). Vitamin D fortification in the United States and Canada: current status and data needs. The American Journal of Clinical Nutrition, 80(6), 1710S-1716S.

Calvo, M. S., Whiting, S. J., \& Barton, C. N. (2005). Vitamin D intake: a global perspective of current status. The Journal of Nutrition, 135(2), 310-316.

Chiu, K. C., Chu, A., Go, V. L. W., \& Saad, M. F. (2004). Hypovitaminosis $D$ is associated with insulin resistance and $\beta$ cell dysfunction. The American Journal of Clinical Nutrition, 79(5), 820-825.

Chiu, K. C., Chuang, L. M., \& Yoon, C. (2001). The vitamin D receptor polymorphism in the translation initiation codon is a risk factor for insulin resistance in glucose tolerant Caucasians. BMC Medical Genetics, 2(1), 2-3.

Cigolini, M., lagulli, M. P., Miconi, V., Galiotto, M., Lombardi, S., \& Targher, G. (2006). Serum 25-hydroxyvitamin D3 concentrations and prevalence of cardiovascular disease among type 2 diabetic patients. Diabetes Care, 29(3), 722724.

Clark, S. A., Stumpf, W. E., \& Sar, M. (1981). Effect of 1, 25 dihydroxyvitamin $\mathrm{D}_{3}$ on insulin secretion. Diabetes, 30(5), 382 386.

Clemens, T. L., Henderson, S. L., Adams, J. S., \& Holick, M. F. (1982). Increased skin pigment reduces the capacity of skin to synthesise vitamin D3. The Lancet, 319(8263), 74-76.

De Boer, I. H., Tinker, L. F., Connelly, S., Curb, J. D., Howard, B. V., Kestenbaum, B., Larson, J. C., Manson, J. E., Margolis, K L., Siscovick, D. S., \& Weiss, N. S. (2008). Calcium plus vitamin $D$ supplementation and the risk of incident diabetes mellitus in the Women's Health Initiative. Diabetes care, 31 , 701-707.

de Lourdes Lima, M., Cruz, T., Rodrigues, L. E., Bomfim, O., Melo, J., Correia, R., Porto, M., Cedro, A., \& Vicente, E. (2009). Serum and intracellular magnesium deficiency in patients with metabolic syndrome-evidences for its relation to insulin resistance. Diabetes Research and Clinical Practice, 83(2), 257-262.

de Souza, C. J., \& Meier, A. H. (1987). Circadian and seasonal variations of plasma insulin and cortisol concentrations in the Syrian hamster, Mesocricetus auratus. Chronobiology International, 4(2), 141-151.

Del Gobbo, L. C., Song, Y., Dannenbaum, D. A., Dewailly, E., \& Egeland, G. M. (2010). Serum 25-Hydroxyvitamin D Is not Associated with Insulin Resistance or Beta Cell Function in 
Canadian Cree, 2. The Journal of Nutrition, 141(2), 290-295.

DeLuca, H. F. (2004). Overview of general physiologic features and functions of vitamin D. The American Journal of Clinical Nutrition, 80(6), 1689S-1696S.

Dilmec, F., Uzer, E., Akkafa, F., Kose, E., \& van Kuilenburg, A. B. (2010). Detection of VDR gene Apal and Taql polymorphisms in patients with type 2 diabetes mellitus using PCR-RFLP method in a Turkish population. Journal of Diabetes and its Complications, 24(3), 186-191.

Donath, M. Y., \& Shoelson, S. E. (2011). Type 2 diabetes as an inflammatory disease. Nature Reviews Immunology, 11(2), 98107.

Donath, M. Y., \& Shoelson, S. E. (2011). Type 2 diabetes as an inflammatory disease. Nature Reviews Immunology, 11(2), 98.

Doró, P., Benkő, R., Matuz, M., \& Soós, G. (2006). Seasonality in the incidence of type 2 diabetes: a population-based study. Diabetes Care, 29(1), 173-173.

Draznin, B. (1988). Intracellular calcium, insulin secretion, and action. The American Journal of Medicine, 85(5), 44-58.

Draznin, B., Sussman, K., Kao, M., Lewis, D., \& Sherman, N. (1987). The existence of an optimal range of cytosolic free calcium for insulin-stimulated glucose transport in rat adipocytes. Journal of Biological Chemistry, 262(30), 1438514388.

Fagard, R. H., \& Nilsson, P. M. (2009). Smoking and diabetesthe double health hazard!. Primary Care Diabetes, 3(4), 205209.

Filus, A., Trzmiel, A., Kuliczkowska-Płaksej, J., Tworowska, U., Jędrzejuk, D., Milewicz, A., \& Mędraś, M. (2008). Relationship between vitamin $\mathrm{D}$ receptor Bsml and Fokl polymorphisms and anthropometric and biochemical parameters describing metabolic syndrome. The Aging Male, 11(3), 134-139.

Fleet, J. C. (2004). Rapid, membrane-initiated actions of 1, 25 dihydroxyvitamin D: what are they and what do they mean? The Journal of Nutrition, 134(12), 3215-3218.

Gastaldelli, A. (2011). Role of beta-cell dysfunction, ectopic fat accumulation and insulin resistance in the pathogenesis of type 2 diabetes mellitus. Diabetes Research and Clinical Practice, 93, S60-S65.

Greenberg, A. S., \& McDaniel, M. L. (2002). Identifying the links between obesity, insulin resistance and $\beta$-cell function: potential role of adipocyte-derived cytokines in the pathogenesis of type 2 diabetes. European Journal of Clinical Investigation, 32, 24-34.

Grønbæk, H., Thomsen, K. L., Rungby, J., Schmitz, O., \& Vilstrup, H. (2008). Role of nonalcoholic fatty liver disease in the development of insulin resistance and diabetes. Expert Review of Gastroenterology \& Hepatology, 2(5), 705-711.

Gulseth, H. L., Gjelstad, I. M., Tierney, A. C., Lovegrove, J. A., Defoort, C., Blaak, E. E., Lopez-Miranda, J., Kiec-Wilk, B., Ris, U., Roche, H. M., \& Drevon, C. A. (2010). Serum vitamin D concentration does not predict insulin action or secretion in European subjects with the metabolic syndrome. Diabetes care, 33(4), 923-925.

Hanley, A. J., Williams, K., Gonzalez, C., D’Agostino, R. B., Wagenknecht, L. E., Stern, M. P., \& Haffner, S. M. (2003). Prediction of type 2 diabetes using simple measures of insulin resistance: combined results from the San Antonio Heart Study, the Mexico City Diabetes Study, and the Insulin Resistance Atherosclerosis Study. Diabetes, 52(2), 463-469.

Herder, C., \& Roden, M. (2011). Genetics of type 2 diabetes: pathophysiologic and clinical relevance. European journal of Clinical Investigation, 41(6), 679-692.

Hirai, M., Suzuki, S., Hinokio, Y., Chiba, M., Kasuga, S., Hirai, A.,
\& Toyota, T. (1998). Group specific component protein genotype is associated with NIDDM in Japan. Diabetologia, 41(6), 742-743.

Hitman, G. A., Mannan, N., McDermott, M. F., Aganna, E., Ogunkolade, B. W., Hales, C. N., \& Boucher, B. J. (1998). Vitamin $D$ receptor gene polymorphisms influence insulin secretion in Bangladeshi Asians. Diabetes, 47(4), 688-690.

Holick, M. F. (2003). Vitamin D: A millenium perspective. Journal of Cellular Biochemistry, 88(2), 296-307.

Holick, M. F. (2011). Vitamin D: evolutionary, physiological and health perspectives. Current Drug Targets, 12(1), 4-18.

Holick, M. F., Chen, T. C., Lu, Z., \& Sauter, E. (2007). Vitamin D and skin physiology: A D-lightful story. Journal of Bone and Mineral Research, 22(S2), V28-V33.

Hussain, M., Naqvi, S. B. S., Khan, M. A., Rizvi, M., Alam, S., Abbas, A., \& Akram, M. U. H. A. M. M. A. D. (2014). Direct cost of treatment of diabetes mellitus type 2 in Pakistan. International Journal of Pharmacy and Pharmaceutical Sciences, 6(11), 261-4.

Imamura, M., \& Maeda, S. (2011). Genetics of type 2 diabetes: the GWAS era and future perspectives. Endocrine Journal, 58(9), 723-739.

Ishaq, M., Khan, G. J., ur Rahman, S., \& Zulfiqar, S. (2013). Prevalence of complications in type 2 diabetes mellitus patients. Pakistan Journal of Physiology, 9(2), 35-37.

Ishimura, E., Nishizawa, Y., Inaba, M., Matsumoto, N., Emoto, M., Kawagishi, T., Shoji, S., Okuno, S., Kim, M., Miki, T., \& Morii, H. (1999). Serum levels of 1, 25-dihydroxyvitamin D, 24, 25-dihydroxyvitamin D, and 25-hydroxyvitamin D in nondialyzed patients with chronic renal failure. Kidney International, 55(3), 1019-1027.

Islam, M. K., Siddhika, A., Manisha, D., Akhter, S., Hassan Z., \& Alis, L., (2014). Association of vitamin D receptor gene Bsm1 $(A>G)$ and Fok1 $(C>T)$ polymorphism in the pathogenesis of impaired glucose tolerance in Bangladeshi subjects. SMU Medical Journal, 1(1), 67-78.

Johnson, J. A., Grande, J. P., Roche, P. C., \& Kumar, R. A. J. I. V. (1994). Immunohistochemical localization of the 1, $25(\mathrm{OH})$ 2D3 receptor and calbindin D28k in human and rat pancreas. American Journal of Physiology-Endocrinology and Metabolism, 267(3), E356-E360.

Jorde, R., Schirmer, H., Wilsgaard, T., Joakimsen, R. M., Mathiesen, E. B., Njølstad, I., Løchen, M.L., Figenschau, Y., Berg, J.P., Svartberg, J., \& Grimnes, G. (2012). Polymorphisms related to the serum 25-hydroxyvitamin D level and risk of myocardial infarction, diabetes, cancer and mortality. The Tromsø Study. PloS one, 7(5), e37295.

Kadowaki, T., Yamauchi, T., Kubota, N., Hara, K., \& Ueki, K. (2008, March). Adiponectin and adiponectin receptors in obesity-linked insulin resistance. Novartis Found Symp., 286, 164-176.

Karohl, C., Su, S., Kumari, M., Tangpricha, V., Veledar, E., Vaccarino, V., \& Raggi, P. (2010). Heritability and seasonal variability of vitamin $D$ concentrations in male twins-. The American Journal of Clinical Nutrition, 92(6), 1393-1398.

Kharroubi, I., Rasschaert, J., Eizirik, D. L., \& Cnop, M. (2003). Expression of adiponectin receptors in pancreatic $\beta$ cells. Biochemical and Biophysical Research Communications, 312(4), 1118-1122.

Konstantinos, P., Banach, M., Bekiari, E., Rizzo M., \& Edmond, M. (2017). Complications of Diabetes. Journal of Diabetes Research, vol. 2018, Article ID 3086167, 4 pages.

Li, J., Byrne, M. E., Chang, E., Jiang, Y., Donkin, S. S., Buhman, K. K., Burgess, J. R., \& Teegarden, D. (2008). 1a, 25 
Dihydroxyvitamin $\mathrm{D}$ hydroxylase in adipocytes. The Journal of Steroid Biochemistry and Molecular Biology, 112(1-3), 122126.

Liel, Y., Ulmer, E., Shary, J., Hollis, B. W., \& Bell, N. H. (1988). Low circulating vitamin D in obesity. Calcified Tissue International, 43(4), 199-201.

Lo, C. W., Paris, P. W., Clemens, T. L., Nolan, J., \& Holick, M. F. (1985). Vitamin D absorption in healthy subjects and in patients with intestinal malabsorption syndromes. The American journal of clinical nutrition, 42(4), 644-649.

Maedler, K. (2008). Beta cells in type 2 diabetes-a crucial contribution to pathogenesis. Diabetes, Obesity and Metabolism, 10(5), 408-420.

Maestro, B., Campión, J., Dávila, N., \& Calle, C. (2000). Stimulation by 1,25-dihydroxyvitamin D3 of insulin receptor expression and insulin responsiveness for glucose transport in U-937 human promonocytic cells. Endocrine Journal, 47(4), 383-391.

Maestro, B., Dávila, N., Carranza, M. C., \& Calle, C. (2003). Identification of a Vitamin D response element in the human insulin receptor gene promoter. The Journal of Steroid Biochemistry and Molecular Biology, 84(2-3), 223-230.

Malecki, M. T., Frey, J., Moczulski, D., Klupa, T., Kozek, E., \& Sieradzki, J. (2003). Vitamin D receptor gene polymorphisms and association with type 2 diabetes mellitus in a Polish population. Experimental and Clinical Endocrinology \& Diabetes, 111(8), 505-509.

Marchetti, P., Del Prato, S., Lupi, R., \& Del Guerra, S. (2006). The pancreatic beta-cell in human Type 2 diabetes. Nutrition, Metabolism and Cardiovascular Diseases, 16, S3-S6.

Marchetti, P., Lupi, R., Federici, M., Marselli, L., Masini, M., Boggi, U., Del Guerra, S., Patanè, G., Piro, S., Anello, M., \& Bergamini, E. (2002). Insulin secretory function is impaired in isolated human islets carrying the Gly972 $\rightarrow$ Arg IRS-1 polymorphism. Diabetes, 51(5), 1419-1424.

Masood, Z., Mahmood, Q., \& Ashraf, K. T. (2010). Vitamin D deficiency-an emerging public health problem in Pakistan. JUMDC, 1(1), 4-9.

Masuda, S., Okano, T., Osawa, K., Shinjo, M., Suematsu, T., \& Kobayashii, T. (1989). Concentrations of vitamin D-binding protein and vitamin D metabolites in plasma of patients with liver cirrhosis. Journal of Nutritional Science and Vitaminology, 35(4), 225-234.

Matsuoka, L. Y., Ide, L., Wortsman, J., Maclaughlin, J. A., \& Holick, M. F. (1987). Sunscreens suppress cutaneous vitamin D3 synthesis. The Journal of Clinical Endocrinology and Metabolism, 64(6), 1165-1168.

Meigs, J. B. (2010). Epidemiology of type 2 diabetes and cardiovascular disease: translation from population to prevention: the Kelly West award lecture 2009. Diabetes Care, 33(8), 1865-1871.

Nagpal, Sunil, Songqing $\mathrm{Na}$, and Radhakrishnan Rathnachalam. "Noncalcemic actions of vitamin D receptor ligands." Endocrine Reviews, 26(5), 662-687.

Norman, A. W. (2006). Vitamin D receptor: new assignments for an already busy receptor. Endocrinology, 147, 5542-5548.

Norman, A. W. 1998. Sunlight, season, skin pigmentation, vitamin $\mathrm{D}$, and 25-hydroxyvitamin $\mathrm{D}$ : integral components of the vitamin D endocrine system. Am. J. Clin. Nutr., 67, 11081110.

Norman, A. W., Frankel, J. B., Heldt, A. M., \& Grodsky, G. M. (1980). Vitamin D deficiency inhibits pancreatic secretion of insulin. Science, 209(4458), 823-825.

Nosratabadi, R., Arababadi, M. K., Salehabad, V. A.,
Shamsizadeh, A., Mahmoodi, M., Sayadi, A. R., \& Kennedy, D. (2010). Polymorphisms within exon 9 but not intron 8 of the vitamin D receptor are associated with the nephropathic complication of type-2 diabetes. International Journal of Immunogenetics, 37(6), 493-497.

Nykjaer, A., Dragun, D., Walther, D., Vorum, H., Jacobsen, C., Herz, J., Melsen, F., Christensen, E. I., \& Willnow, T. E. (1999). An endocytic pathway essential for renal uptake and activation of the steroid 25-(OH) vitamin $\mathrm{D}_{3}$. Cell, 96(4), 507-515.

Ogunkolade, B. W., Boucher, B. J., Prahl, J. M., Bustin, S. A., Burrin, J. M., Noonan, K., North, B. V., Mannan, N., McDermott, M. F., DeLuca, H. F., \& Hitman, G. A. (2002). Vitamin D receptor (VDR) mRNA and VDR protein levels in relation to vitamin $D$ status, insulin secretory capacity, and VDR genotype in Bangladeshi Asians. Diabetes, 51(7), 22942300.

Oh, J. Y., \& Barrett-Connor, E. (2002). Association between vitamin $\mathrm{D}$ receptor polymorphism and type 2 diabetes or metabolic syndrome in community-dwelling older adults: the Rancho Bernardo Study. Metabolism-Clinical and Experimental, 51(3), 356-359.

Omdahl, J. L., Morris, H. A., \& May, B. K. (2002). Hydroxylase enzymes of the vitamin D pathway: expression, function, and regulation. Annual Review of Nutrition, 22(1), 139-166.

Orozco, L. J., Buchleitner, A. M., Gimenez-Perez, G., Roqué, I. F. M., Richter, B., \& Mauricio, D. (2008). Exercise or exercise and diet for preventing type 2 diabetes mellitus. Cochrane Database Syst Rev., 3. CD003054.

Ortlepp, J. R., Lauscher, J., Hoffmann, R., Hanrath, P., \& Joost, H. G. (2001). The vitamin D receptor gene variant is associated with the prevalence of type 2 diabetes mellitus and coronary artery disease. Diabetic Medicine, 18(10), 842-845.

Ortlepp, J. R., Metrikat, J., Albrecht, M., Von Korff, A., Hanrath, P., \& Hoffmann, R. (2003). The vitamin D receptor gene variant and physical activity predicts fasting glucose levels in healthy young men. Diabetic Medicine, 20(6), 451-454.

Orwoll, E., Riddle, M., \& Prince, M. (1994). Effects of vitamin D on insulin and glucagon secretion in non-insulin-dependent diabetes mellitus. The American Journal of Clinical Nutrition, 59(5), 1083-1087.

Pierce, M., Keen, H., \& Bradley, C. (1995). Risk of diabetes in offspring of parents with non-insulin-dependent Diabetes. Diabetic Medicine, 12(1), 6-13.

Pittas, A. G., Dawson-Hughes, B., Li, T., Van Dam, R. M., Willett, W. C., Manson, J. E., \& Hu, F. B. (2006). Vitamin D and calcium intake in relation to type 2 diabetes in women. Diabetes Care, 29(3), 650-656.

Pittas, A. G., Lau, J., Hu, F. B., \& Dawson-Hughes, B. (2007). The role of vitamin $\mathrm{D}$ and calcium in type 2 diabetes. A systematic review and meta-analysis. The Journal of Clinical Endocrinology and Metabolism, 92(6), 2017-2029.

Reaven, G., \& Tsao, P. S. (2003). Insulin resistance and compensatory hyperinsulinemia: the key player between cigarette smoking and cardiovascular disease? Journal of the American College of Cardiology, 41(6), 1044-1047.

Rhee, S. Y., Hwang, Y. C., Chung, H. Y., \& Woo, J. T. (2012). Vitamin D and diabetes in Koreans: analyses based on the Fourth Korea National Health and Nutrition Examination Survey (KNHANES), 2008-2009. Diabetic Medicine, 29(8), 1003-1010.

Sakaki, T., Kagawa, N., Yamamoto, K., \& Inouye, K. (2005). Metabolism of vitamin D3 by cytochromes P450. Frontiers in Bioscience, 10, 119-134.

Scragg, R., Sowers, M., \& Bell, C. (2004). Serum 25- 
hydroxyvitamin D, diabetes, and ethnicity in the Third National Health and Nutrition Examination Survey. Diabetes Care, 27(12), 2813-2818.

Segersten, U., Correa, P., Hewison, M., Hellman, P., Dralle, H., Carling, T., Åkerström, G., \& Westin, G. (2002). 25hydroxyvitamin $D(3)-1$ alpha-hydroxylase expression in normal and pathological parathyroid glands. The Journal of Clinical Endocrinology and Metabolism, 87(6), 2967-2972.

Sergeev, I. N., \& Rhoten, W. B. (1995). 1, 25-Dihydroxyvitamin D3 evokes oscillations of intracellular calcium in a pancreatic beta-cell line. Endocrinology, 136(7), 2852-2861.

Sohail, M. (2014). Prevalence of Diabetic Retinopathy among Type-2 Diabetes Patients in Pakistan-Vision Registry. Pak. J. Ophthalmol., 30(4), 204-212.

Speer, G., Cseh, K., Winkler, G., Vargha, P., Braun, E., Takacs, I., \& Lakatos, P. (2001). Vitamin D and estrogen receptor gene polymorphisms in type 2 diabetes mellitus and in android type obesity. European Journal of Endocrinology, 144(4), 385-389.

Sreelatha, D., P. Laxmi and K. R. Amarnath. 2015. Study of liver function tests in type 2 diabetes mellitus patients. IJPRBS. 5: 39-45.

Sreelatha, S. S., Devi, S. M., Rohini, E., and Seema, S. N. 2015. Prevalence of GDM diagnosed by DIPSI Guidelines. IJPRUR, 4, 841-844.

Strushkevich, N., Usanov, S. A., Plotnikov, A. N., Jones, G., \& Park, H. W. (2008). Structural analysis of CYP2R1 in complex with vitamin $D_{3}$. Journal of Molecular Biology, 380(1), 95-106.

Sung, C. C., Liao, M. T., Lu, K. C., \& Wu, C. C. (2012). Role of vitamin $\mathrm{D}$ in insulin resistance. Journal of Biomedicine and Biotechnology, Volume 2012, Article ID 634195, 11 pages. doi:10.1155/2012/634195.

Szathmary, E. J. (1987). The effect of Gc genotype on fasting insulin level in Dogrib Indians. Human Genetics, 75(4), 368372.

Tripkovic, L., Lambert, H., Hart, K., Smith, C. P., Bucca, G., Penson, S., Chope, G., Hyppönen, E., Berry, J., Vieth, R., \& Lanham-New, S. (2012). Comparison of vitamin D2 and vitamin D3 supplementation in raising serum 25hydroxyvitamin D status: a systematic review and metaanalysis. The American journal of clinical nutrition, 95(6), 1357-1364.

Tworowska-Bardzińska, U., Lwow, F., Kubicka, E., Łaczmański, Ł., Jędzrzejuk, D., Dunajska, K., \& Milewicz, A. (2008). The vitamin $D$ receptor gene Bsm I polymorphism is not associated with anthropometric and biochemical parameters describing metabolic syndrome in postmenopausal women. Gynecological Endocrinology, 24(9), 514-518.

Utzschneider, K. M., Carr, D. B., Hull, R. L., Kodama, K., Shofer, J. B., Retzlaff, B. M., Knopp, R. H., \& Kahn, S. E. (2004). Impact of intra-abdominal fat and age on insulin sensitivity and $\beta$-cell function. Diabetes, 53(11), 2867-2872. van de Bunt, M., Morán, I., Ferrer, J., \& McCarthy, M. I. (2014). Insights into $\beta$-Cell Biology and Type 2 Diabetes Pathogenesis from Studies of the Islet Transcriptome. In Genetics in Diabetes, 23, 111-121.

Vieth, R. (2009). How to optimize vitamin D supplementation to prevent cancer, based on cellular adaptation and hydroxylase enzymology. Anticancer Research, 29(9), 3675-3684.

Vural, H. C., \& Maltas, E. (2012). RT-qPCR assay on the vitamin $D$ receptor gene in type 2 diabetes and hypertension patients in Turkey. Genet Mol Res., 11(1), 582-590.

Wheeler, E., \& Barroso, I. (2011). Genome-wide association studies and type 2 diabetes. Briefings in functional genomics, 10(2), 52-60.

Worrall, D. S., \& Olefsky, J. M. (2002). The effects of intracellular calcium depletion on insulin signaling in 3T3-L1 adipocytes. Molecular Endocrinology, 16(2), 378-389.

Wortsman, J., Matsuoka, L. Y., Chen, T. C., Lu, Z., \& Holick, M. F. (2000). Decreased bioavailability of vitamin $D$ in obesity. The American Journal of Clinical Nutrition, 72(3), 690693.

Wu, T., Willett, W. C., \& Giovannucci, E. (2009). Plasma Cpeptide is inversely associated with calcium intake in women and with plasma 25-hydroxy vitamin D in men. The Journal of Nutrition, 139(3), 547-554.

Ye, W. Z., Reis, A. F., Dubois-Laforgue, D., Bellanne-Chantelot, C., Timsit, J., \& Velho, G. (2001). Vitamin D receptor gene polymorphisms are associated with obesity in type 2 diabetic subjects with early age of onset. European Journal of Endocrinology, 145(2), 181-186.

Zanuso, S., Jimenez, A., Pugliese, G., Corigliano, G., \& Balducci, S. (2010). Exercise for the management of type 2 diabetes: a review of the evidence. Acta Diabetologica, 47(1), 15-22.

Zeitz, U., Weber, K., Soegiarto, D. W., Wolf, E., Balling, R., \& Erben, R. G. (2003). Impaired insulin secretory capacity in mice lacking a functional vitamin $\mathrm{D}$ receptor. The FASEB Journal, 17(3), 509-511.

Zheng, Y., Ley, S. H., \& Hu, F. B. (2018). Global aetiology and epidemiology of type 2 diabetes mellitus and its complications. Nature Reviews Endocrinology, 14(2), 88. 